\title{
EVALUATION OF EXECUTIVE SELECTION FROM PERSPECTVE OF THE CORPORATE REPUTATION: A RESEARCH ON FINANCIAL INSTITUTIONS' EXECUTIVES in TURKEY
}

\author{
Zehra Topal \\ Süleyman Sah University \\ ztopal@ssu.edu.tr \\ Yasemin Torun \\ Süleyman Sah University \\ ytorun@ssu.edu.tr
}

Abstract

In this study, it's examined reasons for executive selection based on data is obtain in Turkish Financial Sector context. Executive selection as an organizational behavior is extensively studied from perspective of contingency theory, resource dependency theory, institutional theory and agency theory. According to the theory of contingency, executive selection decisions depends on the characteristics of executives or performance of executives. On the other hand agency theory perspective sees executives aspects of agency cost. in terms of resource dependency theory, those organizational behaviors are explained by organizations need to manage dependencies. According to resource dependence theory, organizations that are dependent on environmental actors in order to gain power and control provide executive selection. As an intangable asset and strategic tool Corporate Reputation is defined by Fombrun (1996: 70) as "a perceptual representation of a company's past actions and future reprospects that describes the firm's overall appeal to all of its key constituents when compared with other leading rivals". So Corporate Reputation effects its relationship with all stakeholders and it is essential for its survival (Rose, 2004). Leadership and vision is one of the compotent of Corporate Reputation and an important dimension of Reputation measurement. in the Fortune, Management Today, Financial Times, Rayner (2001), Reputation Quotient and Reputex Social Responsibility Ratings (Bebbington, Larrinaga\& Moneva 2008), Management quality and leadership is one of the elements that is focused on evaluation and measurement of the construct. Similarly, in different reputation raking surveys such as Reputation Quotient, Fortune, Capital and Good reputatin index, quality of management is a basic criteria for Corporate Reputation. As leadership and vision can make the organization gain more reputation in the eyes of the stakeholders, a crisis created by the leader can also yield to the loss of the Reputation (Okur ve Akpınar, 2012). Leaders and top management are the most visible people and they represent their companies in all areas. Therefore for the companies want to build a good reputation, protect and development it successfully, leaders and top management is essential. They are expected to hire managers and leaders who contrubute company's Corporate Reputation. Moreover, they are expected to establish selecting criterias that approprate to this aims for management or leader positions. The paper draws on both quantitative and qualititative analyses. Firstly it reveals the demographic profile of executives. Secondly, it applies a discourses analysis of interviews of 82 managers gathered from company magazines or other published materials. According to the results of the study, it is observed that selecting process of candidates for executives of firms heavily takes into account the prestige of the school they graduated and worked in the past. Further, gender is also considered as a matter corporate reputation in this selection process; $\% 92$ of executive positions are occupied by men.

Keywords: Corporate Reputation, Executive Selection, Financial Sector.

\section{INTRODUCTION}

\section{Executive Selective}

Executive turnover decision state that leaving an executive and instead of his or her recruiting another one. Studies in the literature describing the changes in senior management, comes mainly from the position of manager or management team focuses on the characteristics and the relationship between these characteristics and firm performance are questioned. in this context, mainly senior executives visible characteristics, psychological and behavioral profile, success and career history, the business framework and to adapt to the culture of the organization, is focused on strategic vision.

Silzer (2002) describe executives as includes general managers, corporate officers, and heads of major organizational functions and business units. "High potentials" are those accepted to have the potential to become executives. Drucker(1985) mentioned, was quite critical of organizations' success at executive selection: "their batting average is no 
better than. At most one-third of such decisions turn out right; one third are minimally effective; and one-third are outright failures. in no other area ofmanagement would we put up with such miserable performance". Sorcher (1985) writing about the same time reached a similar result (Hollenbeck, 2009).

According to the theory of contingency, executive selection decisions depends on the characteristics of executives or performance of executives. On the other hand agency theory perspective sees executives aspects of agency cost. in terms of resource dependency theory, those organizational behaviors are explained by organizations need to manage dependencies (Pfeffer and Salancik, 2003). Resource dependence theory claim that, organizations that are dependent on environmental actors in order to gain power and control provide via executive selection.

In other respects social capital theory sees managers as a key element of social capital. According to theoreticians, social capital plays a major role in the selection of managers. Besides, managers assigned to a position who brings network and connectivity from past to the position. Network researches which done on executives highlights that social capital constitue social network theory's heart' (Brass \& Krackhardt, 1999: 180).

Institutional approaches suggest a different focus for studies of leadership power in organizations-that interests, power, and politics in organizations are shaped by institutional logics prevailing in wider environments (Fligstein 1990; Friedland and Alford 1991; Powell 1991; Davis and Greve 1997; Meyer et al. 1997). According to this view, while power and politics are present in all organizations, the sources of power, its meaning, and its consequences are contingent on higher-order institutional logics. Institutional logics define the rules of the game by which executive power is gained, maintained, and lost in organizations (Jackall 1988). Moreover, institutional logics are historically variant and are shaped by economic and social structural changes (Fligstein 1985, 1987; Fligstein and Brantley 1992; Barley and Kunda 1992). However, the effects of institutional logics on the determination of power in organizations is not emphasized in most empirical analyses of intraorganizational power or, in particular, in recent studies of succession. While a general theme of both classic and contemporary studies on leadership succession is that organizational politics shape executive change, the idea that the political determinants of succession are themselves conditioned by historical context and institutional logics has been relatively unexplored, with the exception of Fligstein (1982).

\section{Corporate Reputation}

In the dictionary Reputation is defined "The beliefs or opinions that are generally held about someone or something; A widespread belief that someone or something has a particular characteristic (Compact Oxford English Dictionary, 2009). "impression of public esttem or high regard judged by others' (Merriam Websters's Cllegiative Dictionary 1996, p. IOOI). Prior work suggests an organization is held public esteem or high regard when it is viewed as both visible and credible (e.g., established, Professional, and a stable player in the marketplace) (Weiss, 1999).

According to Fombrun (1996:57) 'Corporate Reputations are held by people inside and outsizde a company' (Carmeli, 2005). Deloitte Spain's (2004) defines Corporate Reputation as "the Corporate Reputation of an enterprise is the prestige maintained through tine which, based on a set of shared values and strategies and though the eminence achieved with each stakeholder, assures the sustainability and differentation of the company via the management of its intellectual capital (intagibles).

Corporate Reputation is becaming importante day by day. The international journal 'Corporate Reputation Review (CRR)' is a good example of that. Cravens (2003) explains that by the following words, 'The importance of Reputation in the new economy arguing that ' good reputations create wealth'. Today intagible assets are very important to achieve compatetive advantage and survive and Teece et all. (1997) pointed out that Organizational Reputation as an intagible resource represents an overall assesment of the firm's current asset, position and expected future performance.

Corporate reputation affects the way in which various stakeholders behave towards an organization, influencing, for example, employee retention, customer satisfaction and customer loyality (Chun, 2005). Reputation is said to add value and increase cash flow and profits; first result in increased sales; more credible advertisements; improve percieved product quality and produce higher customer loyality; and attract high quality job applicants thereby enhancing the competitive ability of the firm as well as attracting investors (Caruana, 2005).

Beside having good employee or customer relations and finantial situation, acompany with a good general image is also percieved as having good management. Corporate reputation is a collectively carried out set of beliefs built in a cumulative fashion over time by stakeholders based on the assumption that their interest will be satisfied (Gabbioneta et al., 2007; Gioia at al., 2000) and it will be effective on potantial employees (Stuart, 2002). 
Deephause (2000) emphised that corporate reputation is developed through time with a socially complex process in which the firm and its stakeholders-internal and external are involved. Similarly, De Quevedo (2001) identified two main dimensions of corporate reputation; 'business stakeholders' like workers, managers,shareholders, customers, suppliers and external stakeholders means generally all sociaty.

Fornburn and van Riel (2004) describe as six dimensions of corporate reputation; 1-Emotional Appeal (eg, good feeling about the company), 2-Products and Sevices (eg, offers products that are a good quality, valueand innovative), 3-Vision and Leadership (eg, has great leadreship, well managed), 4-Financial Performance (eg, profitabilty, outperforms competitors), 5-Workplace enviroment (eg, rewards its employees, traits employees fairly), 6-Social Responsibility (support good causes, is enviromentally responsible) (Friedman, 2009).

Reputation of the leader, management or the owner affects the reputation of an organization. By the expression of Murray and White (2004) management is 'at the heart of creating,enhancing and retaining a good reputation'. Many studies have highlighted the importance of the leader's reputation in determining the reputation of an organization's reputation (Klein, 1999; Gumpp and Gaines-Ross, 2002).Management makes the decisions regarding strategy and products or services and creates the company culture in which chiose that affect corporate reputation are mae. Since upper management is the most visible group of employees, the level of trust inspired by upper managament is also an important measure. This trust will also be reflected in the degree to which communication and coordination exists across functional areas and the level of infomration exchange between managers and subordinates (Cravens, 2003).

Leadership is one the most criteria in corporate reputation researches. There is a tight relation between corporate leader and corporate reputation management. Literatelly, the tools that are used to measure corporate reputation like Rep Track Scorecard (RI) and Reputation Quotient (RQ) include leadership and management dimensions. in addition to that, Fortune Magazines well known studies to measure corporate reputation is called America's Most Admired Companies (AMAC) and Global Most Admired Companies (GMAC) include management quality and leadership traits as essencial indicators of corporate reputation.

Kitchen and Laurance's (2003) study consist of more than 1000 managers in 8 counry is shows that, employees and CEO are the most important groups that influence corporate reputation. Corporate leaders need to play an prioner and active role in corporate management. because the leaders internalized the corporate reputation management in the organizations and they represents the organizations by their behavior and personality outside the organizations, they are put in a vital position in corporate reputation management.There is a close relationship between leaders' reputation and corporate reputation (Okur,2012).

Leadership and vision can build up reputation in the sight of stakeholders, they can loss of reputation that generate a crises. Besides corporate leader is the most visible and known person in the eye of stakeholders, he or she should balance between his or her individual reputation and corporate reputation (Davies and Chun, 2009).

Reputation of leaders have impact on corporate reputation. A study is made in different countries show that clearly. This impact is found \% 44 in North America, \%43 in Europe, \%52 in Asia Pasiffic Region and \%55 in Latin American. Generally this ratio is found as \%47 (21. St. Cencury CEO and Corporate Reputation.

Leaders have essencial responsibilities in organizations like, specifiying internal strategies, making external strategies, articulating meaningful mission and vision for their corporation and employees, contolling and montoring applications, motivating and rewarding people. On the other hand they are responsible to give messages to social stakeholders without conflicting with corporate reputation to be a legitimate organization. Leaders and their vision can build a good corporate reputation but sometimes a cris or a mistake is made by them can cause the organization to loose its reputation.

Shortly, if organizations want to have a good reputation they must have a successfull management and leaders. Reputation management and the other efforts to gain and maintain corporate reputation firstly top management and leaders shoud internalize them and act in this way. Then they should build a corporate culture that supports corporate reputation and make all stakeholders to percive their success.

\section{Method}

\section{Participants}

The sample included 81 managers from financial sector except banks in Turkey between the ages of 33-64 of which \%15,7 were women and $\% 84,3$ were men. The mean age was 42,8 . 
Personal Information Form: This form was consisted of questions about age, university that he or she graduated education level, number of years spent in the present position, present company that he or she works, past company that he or she worked, number of years spent outside.

Discource Analysis: This anaylsis applied executives' statement who work at financial sector that 14 different published newspapers and business magazines.

\section{Results}

The main aim of this study was to evaluate the selected executives desicion aspect of corporate reputation. for this purpose, firstly, most preferred executives graduated univesity were investigated. Secondly,gender of executives and past experiment of them were examined. Finally, media visibility of executives were Investigated.All of these dimension discource analysis were evaluated.

\section{Findings of Demographic}

Following the searches inside 83 executives women proportion is $\% 15,7$ and men $\% 84,3$.In this study exeuctives graduated university was examined and universities diveded to two part. One of those part are central universities such as Middle East Technical Univesity, Bosphorus University, Istanbul University. Other part are environs universities which are does not place the biggest five cites. $\% 94,5$ of executives were graduate central university specially as Middle East Technical Univesity and Bosphorus University. The mentioned those three university, instead of report of Reputation Works of Turkey in 2013, the most respected universities of Turkey.\%64,8 of executives posses master degree. Reputation Works of Turkey is conducted by Turkish Commerce University. Age of executives that come their executive position is $\% 45,4$ is in $35-40$ age range, $\% 38,2$ is in $41-45$ age range, $\% 12,3$ is in $46-51$ age range and $\% 8,1$ is in 51 and more age range. Avarage of executives age is 42,8 .

\section{Findings of Experiment}

Following the searches about experiment of executives indicate that $\% 88,6$ of executives are coming Turkey's the most known and respected company such Deniz Bank, Halk Bank, Ziraat Bank and et cetera. Reputation Works of Turkey has revealed that thoso companies which are the most influental firms in Turkey.

\section{Discussion}

\section{Reputation and Managers or Leaders}

Creating reputation is a long and difficult process but at the same time breaking down reputation is very easy and momentary. Altough the actions of all employees are reflected in corporate reputation, upper management and the manager in particular can have a significant individual effect on corporate reputation. The personal reputation of the manager shoul be evaluated. Consider how central the reputation of key manager such as Jack Welch, Rupert Murdoch,Bill Gates and Michael Eisner are to their respective companies (GE, News Corporation, Microsoft and Disney) (Cravens,2003).

Top management team who are respponsible for selection of executives. Previous studies indicate that those members take care of firms reputation when they select executives Top management groups directs actions such as releases, press, conferences, and advertising, referred to here generally as reputation maangement activities, in part to influence stakeholders'perceptions of the firm's reputation. Because top management serves as the guardians and promoter of a firm's image (Gatewood et al., 1993), examining how the Top management group may impact reputation management efforts can be particularly important to understanding why reputation management activities differ across companies (Carter, 2006). Board members attach priority such as to executives because who are represent their reputation in front of stakeholders.

This research clearly indicate that top managers teams tend to select from their manager candidate between Turkey's the best reputable universities. We divided to four man topic those discourses in the context of discource analysis. One of them is education of managers. Instead of education part, top management teams' member thought that managers who is graduated from prestigious universities will make a contribute to the firm's reputations. in our study we found that managers' $\% 94,5$, has got the best universities diploms in Turkey in this sector. By the favour of this selection board members think that managers who are the most visible part of companies generate reputation wtih their individual prestigious. Besides, in 
a survey of more than 600 executives and other top-tier managers, 54 percent believed that at least half of a company's corporate reputation could be attributed to the public image of its executives. Further, 64 percent (versus only 43 percent in 1999) concluded that the ability to maintain and anhance a company's profile must be given substantial weight when choosing a successor (Corporate Board, 2001).

Formbrun (2004) define corporate reputation in his stduy and one of them is Leadership and vision. in this study observed that all executives assigned from Turkey's most reputable firms. Those reputable firms are determined by Reputation Works of Turkey in 2013. Our research found out that $\% 98,8$ of executives who selected by firms coming from banks which are inside most reputable firms in Turkey. This relation imply one of corporate reputations' tools is past experiment where they worked.

A research conducted by Institution Reputation Management, leader is one of the most importante topic that effects the corporatee reputation by the rate of $\% 37.5$ and in Turkey, reputation state that $50.0 \%$ rate with confidence, $41.7 \%$ with a rate of dignity, $16.7 \%$ of the institution by different stakeholders in the eyes of perception, $8.3 \%$ with the ratio values, $6.9 \%$ with quality. According to these results, the largest proportion expressed trust and reputation have seen. Therefore, the leaders who are credible or reliable and keeps their promises can build a good reputation in the eyes of stakeholders. They will crate a trust and their communication and relations with staheholders will improve based on this trust so the quality, deepness and of relations will be effected positively.

Main question of corporate reputation literature is how the corporation is percived by the stakeholders (Wry ve Deephouse, 2007). The answer of this questions is related with and depended on corporation's managers and leaders activities and characteristics. A leader or a manager can effectively manage this perception or change it if it is necceserray. Their messages to the society or public will be influencial according to their personal reputation.

While there are many recent examples of organisations whose leadership and business practice behaviours have destroyed their reputations, such as Enron, Arthur Andersen, Tyco and WorldCom, the positive case for reputation is that it has fostered continued expansion of old stagers like Johnson \& Johnson and Philips, and innovators such as Cisco Systems, who top recent rankings of the most respected organisations in the US and Europe.

\section{References}

[1] Alford, Robert R. (1975). Health Care Politics: Ideological and Interest Group Barriers to Reform. Chicago: University of Chicago Press.

[2] Brass, D.J. \& Krackhardt, D. (1999.) The social capital of 21st century leaders. in J.G. Hunt, G.E. Dodge, \& L. Wong (Eds.), Out-of-the-box leadership, 179-194. Stamford, CT: JAI Press.

[3] Carmeli, A.\& Tishler, A.(2005) "Perceived Organizational Reputation and Organizational Performance: An Empirical Investigation of Industrial Enterprises" Corporate Raputation Rewiev, vol:8. No: 1, 13-30.

[4] Caruana, A., Cohen, C. and Krentler, K.A.(2006) "Corporate Reputation and Intentions: An Attitudinal Perspective." Brand Management Vol. 13, No. 6, 429-440

[5] Chun, Rosa.(2005)"Corporate reputation: Meaning and measurement" International Journal of Management Reviews. , Vol. 7 Issue 2, p91-109. 19p.

[6] Cravens, Karen; Goad Oliver, Elizabeth; Ramamoorti, Sridhar.(2003). "The Reputatio Index;Measuring and Managing Corporate Reputation" European Management Journal. Vol. 21 Issue 2, p201. 212p..

[7] Davies, G and Rosa Chun, "Employee Happiness Isn't Enough To Satisfy Customers." Harvard Business Review (2009).

[8] Davis, Gerald F., and Henrich R. Greve (1997). "Corporate Elite Networks and Governance Changes in the 1980s," American Journal of Sociology 103:1-37.

[9] De Quevedo, E. (2001). Reputación y creación de valor: una relación circular. Aplicación al sector bancario español. Tesis doctoral. Universidad de Burgos.

[10] Deephouse, D.L. (2000) 'Media reputation as a strategic resource. An integration of mass communication and resource-based theories', Journal of Management, 26(6), 1091-1112.

[11] Drucker, P. E. (1985). Getting things done: How to make people decisions. Harvard Business Review, JulyAugust, 22-26. 
[12] Gabionetta C., Ravasi D. and Mazela P. (2007). 'Exploring the drivers of corporate reputation; Astudy of Italian securities analysis'. Corporate Reputation Review. 10(2). 99-123.

[13] Fligstein, Neil. (1990) The Transformation of Corporate Control. Cambridge, MA: Harvard University Press.

[14] Fombrun, C . J and van Riel , C . B . M . (2004) Fame and Fortune: How Successful Companies Build Winning Reputation, Pearson Education, New Jersey.

[15] Friedland, Roger, and Robert R. Alford (1991). "Bringing Society Back In: Symbols, Practices, and Institutional Contradictions." Pp. 232-263 in The New Institutionalism in Organizational Analysis, ed. Walter W. Powell and Paul J. DiMaggio. Chicago: University of Chicago Press.

[16] Friedman B., (2009), 'Human Resources Management Role Implications for Corporate Reputation'. Corporate Reputation Review. Vol:12,3.229-244.

[17] Hollenbeck George P. (2009). "Executive Selection-What's Right . . . and What's Wrong". Industrial and Organizational Psychology, 2 130-143

[18] Kitchen, P. J., and A. Laurence (2003). 'Corporate reputation: an eight-country analysis,' Corporate Reputation Review, 6(2), 103-117.

[19] Meyer, John W., and Brian Rowan. (1977). "Institutionalized Organizations: Formal Structure as Myth and Ceremony," American Journal of Sociology 83: 340-363.

[20] Murray, K., and J. White (2004). CEO Views on reputation management, Chimes Communications, London.

[21] Okur, M.E. and Akpınar, A.T. "Liderin Kurumsal Itibar Yönetimine Etkisi”. Mevzuat Dergisi, Vol,15., No.174, June 2012.

[22] Pfeffer J., Salancik G. (2003). "The External Control of Organizations A Resource Dependency Perspective". Standford University Press, ISBN: 9780804748704

[23] Powell, Walter W. (1999). "The Social Construction of an Organizational Field: The Case of Biotechnology," International Journal of Biotechnology 1:42-66

[24] Rose, C. and Thompsen, S. "The Impact of Corporate Reputation on Performance: Some Danish Evidence " European Management Journal Vol. 22, No. 2, pp. 201-210, 2004.

[25] Silzer, R. (2002). Preface. in R. Silzer (Ed.), The 21st century executive: Innovative practices for building leadership at the top. San Francisco: Jossey-Bass.

[26] Sorcher, M. (1985). Predicting executive success. New York: John Wiley \& Sons.

[27] Teece, D.J., Pisano, G. and Shuen, A. (1997) 'Dynamic capabilities and strategic management', Strategic Management Journal, 18(7), 509-533.

[28] Weiss, A.M., Anderson, E. and Maclnnis, D.J. (1999). Reputation management as a motivation for sales structure decisions. Journal of Marketing, 63, 74- 89.

[29] Wry T and Deephouse D L (2007), "An Examination of the Relationship between Corporate Social Performance and Stakeholder Perceptions of Corporate Social Performance", http://www.reputationinstitute.com/members/nyc06/wry.pdf (15.11.2009).

[30] Zabala, I., Panadero, G., Gallardo, L.M., Amate, C.M., Sa' nchez-Galindo, M., Tena, I. and Villalba, I. "Corporate Reputation in Professional Services Firms: 'Reputation Management Based on Intellectual Capital Management' Corporate Reputation Review, Vol. 8, No. 1, 2005, pp. 59-71. 